\title{
PERBEDAAN KADAR TRIGLISERIDA SEBELUM DAN SETELAH PEMBERIAN SARI BENGKUANG (PACHYRRHIZUS EROSUS) PADA WANITA
}

\author{
Azhoranezar Ramadhani, Enny Probosari*) \\ Program Studi Ilmu Gizi Fakultas Kedokteran Universitas Diponegoro \\ Jl.Dr.Sutomo No.18, Semarang, Telp (024) 8453708, Email : gizifk@undip.ac.id
}

\begin{abstract}
Background : Cardiovascular disease can be caused by a condition called hypertriglyceridemia. Hypertriglyceridemia is a condition in which blood triglyceride levels are above the normal limit. Triglyceride levels in blood was influenced by the intake of fats and carbohydrates. Consumption of foods containing vitamin $C$, fiber and flavonoids can reduce blood triglyceride levels, one of which is the fruit of yam bean. This study aims to determine the difference triglyceride levels before and after administration of yam bean essence (Pachyrrhizus erosus) in women.

Method : This study was a true experimental design with a control group pre-post test. Subjects were employees aged 40-50 years, as many as 28 people that have triglyceride levels of 100-200 mg/dl. Subjects were divided into 2 groups (treatment and control), each group consisted of 14 people. The intervention was conducted for 21 days. The treatment group was given yam bean essence that is made from 320 gram of yam bean, and the control group was given a placebo in the form of low calorie syrup. Blood triglyceride levels before and after the intervention were taken after the subjects fasted for 10 hours and analyzed using the GPOP-PAP method. The normality test uses Shapiro Wilk. Statistical analyzes using dependent t-test, independent t-test, Mann Whitney, and Wilcoxon.

Result : Mean triglyceride levels before the intervention in the treatment group is $145 \pm 24,08 \mathrm{mg} / \mathrm{dl}$ and decrease to $130 \pm 22,95 \mathrm{mg} / \mathrm{dl}$ after the intervention. There is a significant differences triglyceride levels in the treatment group

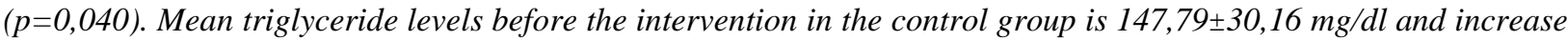
to $164,71 \pm 27,09 \mathrm{mg} / \mathrm{dl}$ after the intervention. There is a significant differences triglyceride levels in the control group $(p=0,022)$. The statistical test showed significant difference $(p=0,001)$ of triglyceride levels beetwen the two groups.
\end{abstract}

Conclusion : There is a significant decrease in triglyceride levels as much as $14,93 \mathrm{mg} / \mathrm{dl}$ after consumption yam bean essence that is made from 320 gram of yam bean.

Keywords : yam bean; yam bean essence; triglyceride

\begin{abstract}
ABSTRAK
Latar belakang : Penyakit jantung dan pembuluh darah dapat disebabkan karena suatu kondisi yang disebut hipertrigliseridemia. Hipertrigliseridemia merupakan suatu kondisi dimana kadar trigliserida dalam darah lebih dari batas normal. Kadar trigliserida dalam darah dipengaruhi oleh asupan lemak dan karbohidrat. Konsumsi bahan makanan yang yang mengandung vitamin $C$, serat, dan flavonoid dapat menurunkan kadar trigliserida dalam darah, salah satunya adalah buah bengkuang. Penelitian ini bertujuan untuk mengetahui perbedaan kadar trigliserida sebelum dan setelah pemberian sari bengkuang (Pachyrrhizus erosus) pada wanita.

Metode : Penelitian ini merupakan true experimental dengan rancangan control group pre-post test. Subjek penelitian adalah wanita berusia 40-50 tahun sebanyak 28 orang yang memiliki kadar trigliserida 100-200 mg/dl. Subjek dibagi menjadi 2 kelompok, yaitu kelompok perlakuan dan kontrol dimana setiap kelompok terdiri dari 14 orang. Pemberian intervensi dilakukan selama 21 hari. Kelompok perlakuan diberikan sari bengkuang yang didapat dari 320 gram buah bengkuang, dan kelompok kontrol diberikan plasebo berupa air sirup rendah kalori. Kadar trigliserida darah sebelum dan setelah intervensi diambil setelah subjek berpuasa selama 10 jam dan dianalisis menggunakan metode GPO-PAP. Uji normalitas menggunakan Shapiro Wilk. Analisis statistik menggunakan dependent t-test, independent t-test, Mann Whitney, dan Wilcoxon.

Hasil : Rerata kadar trigliserida sebelum intervensi pada kelompok perlakuan adalah 145 $\pm 24,08 \mathrm{mg} / \mathrm{dl}$ dan mengalami penurunan menjadi $130 \pm 22,95 \mathrm{mg} / \mathrm{dl}$ setelah intervensi. Terdapat perbedaan yang bermakna kadar trigliserida pada kelompok perlakuan $(p=0,040)$. Rerata kadar trigliserida sebelum intervensi pada kelompok

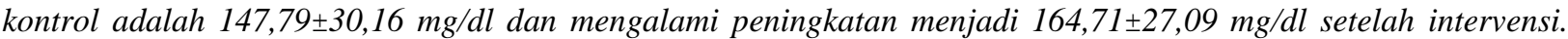
Terdapat perbedaan bermakna kadar trigliserida pada kelompok kontrol ( $p=0,022)$. Uji statistik menunjukkan terdapat perbedaan yang bermakna pada kadar trigliserida antar kedua kelompok setelah intervensi $(p=0,001)$.

Simpulan : Terdapat penurunan kadar trigliserida sebanyak 14,93 mg/dl setelah mengkonsumsi sari bengkuang yang diperoleh dari buah bengkuang seberat 320 gram.
\end{abstract}

Kata kunci : bengkuang; sari bengkuang; trigliserida 


\section{PENDAHULUAN}

Penyakit jantung dan pembuluh darah adalah salah satu penyebab utama kematian di beberapa bagian dunia. ${ }^{1}$ Sampai saat ini kematian akibat penyakit jantung dan pembuluh darah mencapai 17,5 juta didunia. Hal ini setara dengan $30 \%$ kematian di dunia yang disebabkan oleh penyakit tersebut. Diperkirakan akan ada sekitar 20 juta penderita penyakit jantung dan pembuluh darah yang meninggal sampai tahun 2015 dan 23,6 juta penderita sampai tahun $2030 .^{2}$ Berdasarkan profil kesehatan Provinsi Jawa Tengah, penyakit jantung dan pembuluh darah merupakan kejadian penyakit yang tertinggi yaitu sebesar $62,43 \%$ pada tahun 2011. ${ }^{3}$ Dinas Kesehatan Kota Semarang tahun 2012 melaporkan terdapat 8.462 kasus penyakit jantung dan pembuluh darah dengan rentang umur 15-64 tahun. ${ }^{4}$ Salah satu faktor risiko terjadinya penyakit jantung dan pembuluh darah adalah dislipidemia. Mengatasi masalah dislipidemia dapat menurunkan kejadian penyakit jantung dan pembuluh darah. ${ }^{5}$

Dislipidemia merupakan keadaan dimana terjadi kelainan metabolisme lemak. Kolesterol HDL kadarnya akan mengalami penurunan dalam darah. Sedangkan kolesterol total, trigliserida dan kolesterol LDL akan mengalami peningkatan. ${ }^{6}$ Tingginya kadar trigliserida darah disebut hipertrigliseridemia. ${ }^{7}$ Sebuah penelitian telah menyebutkan bahwa ada hubungan antara tingginya kadar trigliserida dalam darah dengan risiko penyakit jantung dan pembuluh darah, yaitu pada pria sebanyak $13 \%$ dan pada wanita sebanyak $37 \%{ }^{1}$

Kadar trigliserida normal dalam darah adalah $<150 \mathrm{mg} / \mathrm{dl}$, sedangkan dikatakan tinggi apabila $>150 \mathrm{mg} / \mathrm{dl} .{ }^{7}$ Penelitian yang dilakukan di kota Semarang pada tahun 2007-2008, menyebutkan bahwa kadar trigliserida dalam darah $>150 \mathrm{mg} / \mathrm{dl}$ meningkatkan risiko terjadinya penyakit jantung dan pembuluh darah sebesar 2,8 kali lebih besar dibandingkan dengan kadar trigliserida darah $<150 \mathrm{mg} / \mathrm{dl} .^{8}$

Kadar trigliserida dipengaruhi oleh beberapa faktor, yaitu usia, jenis kelamin dan aktivitas fisik. Pada sebuah penelitian di Dinas Kesehatan Sulawesi Selatan, tingkat aktivitas fisik pekerja kantoran termasuk dalam kategori sedang dan rendah. Selain itu pekerja kantoran yang memiliki status gizi lebih mempunyai pola makan yang kurang baik dan aktivitas fisik yang rendah. ${ }^{9}$ Aktivitas fisik yang kurang dan pola makan yang salah berisiko mengalami penumpukan lemak serta trigliserida dalam tubuh. ${ }^{10}$
Kadar trigliserida dalam darah juga dipengaruhi oleh asupan. Asupan lemak dan karbohidrat yang berlebihan dapat meningkatkan kadar trigliserida dalam darah. Trigliserida yang tinggi dapat diatasi dengan cara mengatur asupan. ${ }^{5}$ Konsumsi sayur dan buah yang tinggi akan serat serta vitamin dapat menurunkan kadar trigliserida dalam darah. ${ }^{11}$ Jenis buah tersebut salah satunya adalah bengkuang.

Bengkuang merupakan tanaman akar yang umbinya dapat dikonsumsi. Di Indonesia, budidaya bengkuang banyak ditemukan di pulau jawa. Bengkuang mudah didapat, karena masa panen bengkuang tidak tergantung dari musim. Harga bengkuang di pasar juga terjangkau sehingga dapat dikonsumsi untuk semua golongan masyarakat. ${ }^{12}$ Saat ini, berbagai macam olahan bengkuang banyak dipakai dalam bidang kecantikan, sedangkan pada bidang kesehatan, bengkuang belum banyak diteliti.

Bengkuang memiliki kandungan zat gizi yang baik dikonsumsi untuk kesehatan, salah satunya adalah serat larut air. Serat larut air berfungsi dalam penurunan kadar trigliserida. ${ }^{13}$ Serat yang larut dalam air memperlambat perjalanan makanan yang melalui usus. ${ }^{14}$ Sebuah penelitian telah menunjukkan bahwa serat dapat menurunkan kadar trigliserida secara signifikan. ${ }^{13}$

Bengkuang dapat diolah menjadi berbagai macam produk. Produk olahan buah bengkuang agar mudah untuk dikonsumsi salah satunya adalah sari bengkuang. Sari bengkuang merupakan sumber vitamin $\mathrm{C}$, polifenol dan flavonoid yang ketiganya berfungsi sebagai antioksidan. ${ }^{15}$ Polifenol dan flavonoid berpengaruh dalam penurunan risiko penyakit jantung dan pembuluh darah. ${ }^{16}$ Pada sebuah penelitian, diketahui bahwa sari bengkuang (Pachyrrhizus erosus) berpengaruh terhadap penurunan kadar kolesterol dalam darah pada tikus putih (Rattus Norvegicus). ${ }^{15}$

Pengaruh pemberian ekstrak bengkuang terhadap kadar trigliserida sudah pernah diujikan pada tikus putih, dimana kadar trigliserida tikus putih menunjukkan penurunan yang signifikan setelah pemberian ekstrak bengkuang. ${ }^{17}$ Pemberian sari bengkuang terhadap kadar trigliserida manusia belum pernah diujikan. Berdasarkan permasalahan diatas, maka perlu dilakukan penelitian lebih lanjut, yaitu perbedaan kadar trigliserida sebelum dan setelah pemberian sari bengkuang (Pachyrrhizus erosus) pada wanita.

\section{METODE PENELITIAN}

Penelitian ini merupakan penelitian true experimental dengan rancangan control group pre- 
post test. Variabel bebas dalam penelitian ini adalah pemberian sari bengkuang dan variabel terikatnya adalah kadar trigliserida wanita, sedangkan variabel perancunya adalah asupan zat gizi. Pelaksanaan penelitian telah mendapat persetujuan dari Komite Etik Fakultas Kedokteran Universitas Diponegoro melalui terbitnya Etichal Clearance.

Subjek penelitian adalah karyawati Kanwil DJPB (Direktorat Jenderal Perbendaharaan) dan Badan Pertanahan Kota Semarang. Kriteria inklusi penelitian ini wanita dengan usia 40-50 tahun yang memiliki kadar trigliserida 100-200 mg/dl. Subjek tidak dalam keadaan hamil atau menyusui, tidak mengkonsumsi alkohol dan tidak merokok. Selain itu, subjek juga belum mengalami menopause, tidak sedang mengkonsumsi obat antihiperlipidemia selama penelitian, tidak dalam keadaan sakit atau perawatan dokter berkaitan dengan penyakit jantung koroner, diabetes melitus, maupun penyakit kronik lainnya, bersedia menjadi subjek penelitian dengan mengisi informed consent, dan dapat diajak berkomunikasi. Subjek yang dipilih adalah yang memiliki aktivitas fisik dengan kategori kurang aktif.

Data aktivitas fisik dikumpulkan menggunakan kuesioner aktivitas fisik Baecke (1982). Aktivitas fisik yang yang dimaksud adalah aktivitas fisik saat berolahraga dan pada waktu luang, karena pekerjaan seluruh subjek sama, yaitu karyawati. Aktivitas fisik subjek dihitung menggunakan rumus indeks aktivitas olah raga dan indeks aktivitas waktu luang. ${ }^{18}$ Pengkategorian aktivitas fisik adalah sangat aktif, aktif, cukup aktif, kurang aktif, dan sangat tidak aktif, dimana seluruh subjek yang termasuk dalam kriteria inklusi adalah subjek yang memiliki aktivitas fisik dalam kategori kurang aktif. Data status gizi subjek dihitung dengan menggunakan rumus Indeks Masa Tubuh (IMT) dengan kategori underweight, normal, overweight, dan obesitas. ${ }^{19}$ Tidak ada pembatasan status gizi subjek untuk masuk dalam kriteria inklusi pada penelitian ini.

Penentuan subjek dilakukan dengan metode consecutive sampling, dan didapatkan 96 orang yang bersedia diambil darahnya untuk proses skrinning awal. Subjek yang memenuhi kriteria inklusi sebanyak 28 orang. Subjek dibagi menjadi 2 kelompok, yaitu kelompok perlakuan dan kelompok kontrol dengan metode simple randomization sehingga diperoleh 14 sampel pada tiap kelompok. Tidak ada subjek yang drop out pada penelitian ini. Kelompok perlakuan mendapat sari bengkuang dari 320 gram buah bengkuang, sedangkan kelompok kontrol mendapatkan plasebo berupa air sirup rendah kalori. Pemberian sari bengkuang dan plasebo dilakukan selama 21 hari.

Sari bengkuang diperoleh dari buah bengkuang seberat 320 gram yang telah dikupas dan dicuci bersih. Setelah itu, buah bengkuang diambil sarinya menggunakan juicer dengan merk cosmos dan menghasilkan $\pm 250 \mathrm{ml}$ sari bengkuang. Sari bengkuang dikemas dalam gelas plastik yang ditutup rapat dengan menggunakan alat cup sealer. Kandungan zat gizi dalam sari bengkuang telah diujikan di UPT Laboratorium Pangan Universitas Muhammadiyah semarang (UNIMUS). Berdasarkan hasil uji yang dilakukan, sari bengkuang sebanyak $\pm 250 \mathrm{ml}$ mengandung vitamin C 13,8565 $\mathrm{mg}$, serat kasar 3,942 mg, oligosakarida 44,0405 mg, dan flavanoid 26,45\%. Plasebo pada penelitian ini terbuat dari 2 sendok makan sirup rendah kalori yang ditambahkan air sebanyak $\pm 200 \mathrm{ml}$.

Kadar trigliserida dianalisis dengan menggunakan metode GPO-PAP (Glycerol Phosphate Oxidase-Phenol Amino Phenazone). Sampel darah diambil sebanyak 2 kali, yaitu 2 hari sebelum intervensi dan 1 hari setelah intervensi (pada hari ke-22) oleh petugas laboratorium setelah subjek berpuasa selama 10 jam.

Variabel perancu pada penelitian ini adalah asupan zat gizi, yaitu karbohidrat, lemak, protein, serat, vitamin $\mathrm{C}$ dan kolesterol. Zat gizi tersebut berasal dari konsumsi makanan dan minuman selama intervensi, kemudian dicatat pada formulir food recall. Data asupan zat gizi diperoleh dalam bentuk ukuran rumah tangga (URT) dan dikonversikan kedalam satuan gram, kemudian dihitung menggunakan program nutrisoft.

Uji normalitas menggunakan uji ShapiroWilk. Karakteristik subjek dianalisis dengan menggunakan analisis deskriptif. Perbedaan kadar trigliserida sebelum intervensi pada kedua kelompok diuji dengan menggunakan uji MannWhitney, sedangkan perbedaan kadar trigliserida setelah intervensi pada kedua kelompok menggunakan uji Independent t. Perbedaan kadar trigliserida sebelum dan setelah intervensi pada kelompok perlakuan diuji dengan uji dependent $t$, sedangkan perbedaan kadar trigliserida sebelum dan setelah intervensi pada kelompok kontrol menggunakan uji Wilcoxon. Semua uji yang dilakukan menggunakan tingkat kepercayaan $95 \%$.

\section{HASIL PENELITIAN Karakteristik Subjek}

Karakteristik subjek yang terdiri dari gambaran umur, status gizi, dan aktivitas fisik sebelum penelitian disajikan dalam tabel 1 . 
Tabel 1. Karakteristik subjek

\begin{tabular}{|c|c|c|c|c|c|c|c|}
\hline \multirow{2}{*}{ Karakteristik subjek } & \multicolumn{3}{|c|}{ Perlakuan $(n=14)$} & \multicolumn{3}{|c|}{ Kontrol $(n=14)$} & \multirow[t]{2}{*}{$\mathbf{p}$} \\
\hline & Mean \pm SD & n & $\%$ & Mean \pm SD & $\mathbf{n}$ & $\%$ & \\
\hline $\begin{array}{l}\text { Umur } \\
40-50\end{array}$ & $47,79 \pm 2,42$ & 14 & 50 & $46,00 \pm 3,68$ & 14 & 50 & $0,234^{1}$ \\
\hline $\begin{array}{l}\text { Status Gizi }\left(\mathrm{kg} / \mathrm{m}^{2}\right) \\
\text { Normal }(18,2-22,9) \\
\text { Overweight }(23-24,9) \\
\text { Obesitas }(\geq 25)\end{array}$ & $\begin{array}{l}22,26 \pm 0,49 \\
23,53 \pm 0,50 \\
31,14 \pm 5,61\end{array}$ & $\begin{array}{l}3 \\
3 \\
8\end{array}$ & $\begin{array}{l}10,7 \\
10,7 \\
28,6\end{array}$ & $\begin{array}{l}21,01 \pm 0,75 \\
24,11 \pm 0,67 \\
28,12 \pm 1,32\end{array}$ & $\begin{array}{l}4 \\
4 \\
6\end{array}$ & $\begin{array}{l}14,3 \\
14,3 \\
21,4\end{array}$ & $0,270^{2}$ \\
\hline $\begin{array}{l}\text { Aktivitas Subjek } \\
\text { Kurang Aktif }(1,5-2,5)\end{array}$ & $1,53 \pm 0,01$ & 14 & 50 & $1,52 \pm 0,01$ & 14 & 50 & $0,176^{2}$ \\
\hline
\end{tabular}

${ }^{1}$ Uji beda Mann-Whitney

${ }^{2} \mathrm{Uji}$ beda Independent $t$

Semua subjek dalam penelitian ini adalah wanita berusia 40-50 tahun. Subjek memiliki status gizi normal, overweight dan obesitas. Pada kelompok perlakuan maupun kontrol, subjek yang memiliki status gizi obesitas lebih banyak, yaitu masing-masing 8 orang $(28,6 \%)$ dan 6 orang $(21,4 \%)$. Aktivitas fisik subjek pada kelompok perlakuan dan kontrol termasuk dalam kategori kurang aktif. Hasil statistik menyebutkan bahwa tidak ada perbedaan umur, status gizi dan aktivitas subjek antar kedua kelompok ( $\mathrm{p}>0,05)$.

\section{Asupan Zat Gizi}

Asupan zat gizi, yaitu karbohidrat, protein, lemak, serat, vitamin $\mathrm{C}$, dan kolesterol dapat mempengaruhi kadar trigliserida. Asupan zat gizi subjek pada kelompok perlakuan dan kontrol selama intervensi dapat dilihat pada tabel 2 .

Tabel 2. Asupan makan subjek kelompok perlakuan dan kontrol selama intervensi

\begin{tabular}{lccc}
\hline & Perlakuan $(\mathbf{n}=\mathbf{1 4})$ & Kontrol $(\mathbf{n}=\mathbf{1 4})$ & $\mathbf{p}$ \\
& Mean \pm SD & Mean \pm SD & \\
\hline Energi (kkal) & $1282,14 \pm 285,43$ & $1293,57 \pm 310,39$ & $0,945^{1}$ \\
Karbohidrat $(\mathbf{g})$ & $169,51 \pm 41,06$ & $183,25 \pm 54,30$ & $0,748^{1}$ \\
Protein (g) & $43,32 \pm 9,37$ & $39,54 \pm 10,29$ & $0,318^{2}$ \\
Lemak (g) & $48,68 \pm 18,13$ & $46,46 \pm 12,74$ & $0,711^{2}$ \\
Serat $(\mathbf{g})$ & $8,71 \pm 2,75$ & $8,29 \pm 1,95$ & $0,649^{2}$ \\
Vitamin C (mg) & $54,29 \pm 23,57$ & $45,9 \pm 25,52$ & $0,375^{2}$ \\
Kolesterol (g) & $190,49 \pm 99,39$ & $160,92 \pm 48,08$ & $0,462^{1}$ \\
\hline
\end{tabular}

${ }^{1}$ Uji beda Mann-Whitney

${ }^{2}$ Uji beda Independent $t$

Berdasarkan hasil pada tabel 2, tidak ada perbedaan asupan energi, dan zat gizi yaitu karbohidrat, protein, lemak, serat, vitamin $\mathrm{C}$ dan kolesterol antara kelompok perlakuan dan kontrol $(\mathrm{p}>0,05)$. Data asupan energi dan zat gizi hanya dilakukan selama intervensi.

\section{Perbedaan Kadar Trigliserida Sebelum dan Setelah Pemberian Sari Bengkuang}

Perbedaan kadar trigliserida sebelum dan setelah intervensi pada kelompok perlakuan dan kontrol disajikan pada tabel 3.

Tabel 3. Perbedaan kadar trigliserida pada kelompok perlakuan dan kontrol.

\begin{tabular}{lccc}
\hline \multicolumn{1}{c}{ Variabel } & $\begin{array}{c}\text { Perlakuan }(\mathbf{n}=\mathbf{1 4}) \\
\text { Mean } \pm \text { SD }\end{array}$ & $\begin{array}{c}\text { Kontrol }(\mathbf{n}=14) \\
\text { Mean } \pm \text { SD }\end{array}$ & p \\
\hline Kadar Trigliserida & & & \\
Awal & $145 \pm 24,08$ & $147,79 \pm 30,16$ & $0,936^{2}$ \\
Akhir & $130 \pm 22,95$ & $164,71 \pm 27,09$ & $0,001^{1}$ \\
$\Delta$ penurunan & $-14,93 \pm 24,57$ & $17,00 \pm 23,42$ & $0,002^{1}$ \\
p & $0,040^{\mathrm{a}}$ & $0,022^{\mathrm{b}}$ & \\
\hline
\end{tabular}

${ }^{\text {a }}$ Uji beda Dependent $t, \quad{ }^{\mathrm{b}}$ Uji beda Wilcoxon

${ }^{1}$ Uji beda Independent $t, \quad{ }^{2}$ Uji beda Mann Whitney

Hasil uji beda pada tabel 3 , menunjukkan adanya perbedaan kadar trigliserida yang bermakna sebelum dan setelah perlakuan pada masing-masing kelompok $\quad(\mathrm{p}<0,05)$. Pada kelompok perlakuan, terjadi penurunan kadar trigliserida sebesar $14,93 \pm 24,57 \mathrm{mg} / \mathrm{dl}$ atau $10 \%$, 
sedangkan pada kelompok kontrol terjadi peningkatan kadar trigliserida sebesar 17,00 $\pm 23,42$ $\mathrm{mg} / \mathrm{dl}$ atau $11 \%$. Pada kelompok perlakuan terdapat 10 subjek yang mengalami penurunan kadar trigliserida, dan 4 subjek yang mengalami peningkatan. Pada kelompok kontrol, terdapat 10 subjek yang mengalami peningkatan kadar trigliserida dan 4 subjek yang mengalami penurunan. Setelah pemberian intervensi, terdapat perbedaan bermakna kadar trigliserida pada kedua kelompok.

\section{PEMBAHASAN}

Risiko penyakit jantung dan pembuluh darah semakin bertambah setelah usia 40 tahun pada wanita. Hal ini disebabkan karena hormon estrogen yang semakin menurun seiring bertambahnya usia. ${ }^{20}$ Penyakit jantung dan pembuluh darah juga dapat terjadi karena adanya kadar trigliserida yang tidak normal dalam tubuh. ${ }^{21}$ Karakteristik subjek dalam penelitian ini adalah wanita berusia 40-50 tahun serta memiliki tingkat aktivitas fisik yang sama. Berdasarkan data aktivitas fisik subjek yang dikumpulkan menggunakan kuesioner aktivitas fisik Baecke $(1982)^{16}$, aktivitas fisik subjek termasuk dalam kategori kurang aktif. Subjek yang dipilih pada penelitian ini homogen, karena berdasarkan hasil uji statistik, tidak terdapat perbedaan yang bermakna karakteristik subjek (umur, akitivitas fisik, dan status gizi) antar kedua kelompok.

Pada penelitian ini, terdapat subjek dengan status gizi normal $25 \%$, overweight $25 \%$ dan obesitas 50\%. Wanita dengan status gizi lebih (overweight dan obesitas) memiliki risiko yang lebih besar terhadap penyakit jantung dan pembuluh darah. Suatu penelitian menyebutkan bahwa penderita penyakit jantung dan pembuluh dengan status gizi overweight dan obesitas memiliki kadar trigliserida $\geq 150 \mathrm{mg} / \mathrm{dl} .{ }^{21}$ Penderita obesitas memiliki kelainan hormon leptin yang dapat mengganggu dalam pengontrolan nafsu makan dan menyebabkan terjadinya gangguan metabolisme lipoprotein yang ditandai dengan meningkatnya kadar trigliserida dan ester kolesterol. ${ }^{22}$

Kadar trigliserida dalam tubuh salah satunya dapat dipengaruhi oleh asupan energi dan zat gizi. Pada penelitian ini, asupan energi dan zat gizi (karbohidrat, protein, lemak, serat, vitamin C, dan kolesterol) tidak menunjukkan perbedaan yang bermakna pada kelompok perlakuan dan kontrol. Pengumpunlan data asupan energi dan zat gizi dilakukan selama pemberian intervensi.
Berdasarkan hasil analisis statistik, terdapat perbedaan rerata yang bermakna pada kadar trigliserida setelah diberikan sari bengkuang. Rerata kadar trigliserida sebelum diberikan sari bengkuang $145 \pm 24,08 \mathrm{mg} / \mathrm{dl}$ dan setelah diberikan sari bengkuang menjadi $130 \pm 22,95 \mathrm{mg} / \mathrm{dl}$. Perbedaan ini menunjukkan adanya penurunan sebesar 14,93 mg/dl. Hal ini berkaitan dengan penambahan sari bengkuang pada kelompok perlakuan.

Kandungan sari bengkuang seperti vitamin C, serat, dan flavonoid mempengaruhi metabolisme trigliserida dalam tubuh. Flavonoid dapat mencegah oksidasi LDL dan mengurangi lipid peroksidasi. ${ }^{23}$ Penelitian sebelumnya menyebutkan bahwa vitamin $\mathrm{C}$ menghambat sekresi hormon leptin. ${ }^{24}$ Pada keadaaan ini terjadi lipolisis dimana enzim Hormone Sensitive Lipase (HSL) menghidrolisis trigliserida menjadi asam lemak dan gliserol. ${ }^{25}$

Konsumsi serat juga mempengaruhi metabolisme trigliserida dalam tubuh. Sebuah penelitian menyebutkan bahwa konsumsi tinggi serat dapat menurunkan kadar trigliserida. ${ }^{13}$ Serat larut air berfungsi dalam memperlambat waktu pengosongan lambung, meningkatkan ketebalan lapisan intestinal yang berfungsi sebagai tempat absorpsi lipid. Selain itu, serat larut air dapat menghambat absorpsi dan metabolisme asam empedu dengan cara mengikat asam empedu dan meningkatkan pengeluarannya melalui feses. ${ }^{26}$

Kadar trigliserida pada kelompok kontrol juga menunjukkan perbedaan rerata yang bermakna setelah pemberian air sirup rendah kalori. Perbedaan ini menunjukkan adanya peningkatan rerata kadar trigliserida sebesar 17 $\mathrm{mg} / \mathrm{dl}$. Hal ini berkaitan dengan asupan zat gizi subjek. Salah satu asupan zat gizi yang mempengaruhi kadar trigliserida darah adalah karbohidrat. Konsumsi tinggi karbohidrat dapat memicu terjadinya kenaikan kadar trigliserida. ${ }^{27}$ Pada penelitian ini asupan karbohidrat kedua kelompok tidak menunjukkan perbedaan yang bermakna, namun asupan karbohidrat pada kelompok kontrol lebih tinggi dibandingkan kelompok perlakuan. Hal inilah yang diduga dapat menunjang kenaikan kadar trigliserida. Karbohidrat yang masuk ke dalam tubuh dipecah menjadi glukosa yang akan mengalami glikolisis. Mekanisme pemecahan glukosa melalui berbagai tahapan, diantaranya melalui pemecahan dehidroksiaseton fosfat menjadi gliserol 3 fosfat. Gliserol 3 fosfat adalah komponen penyusun trigliserida dalam tubuh, sehingga dengan 
meningkatnya gliserol 3 fosfat juga menyebabkan meningkatnya kadar trigliserida dalam tubuh. ${ }^{27}$

Selain asupan karbohidrat, yang berpengaruh terhadap kadar trigliserida adalah asupan serat dan vitamin C. Asupan serat dan vitamin C pada kelompok kontrol sebesar $8,29 \pm 1,95 \mathrm{~g}$, dan 45,9 $\pm 25,52 \mathrm{mg}$. Anjuran kecukupan zat gizi harian yang direkomendasikan oleh American Dietetic Association (ADA) atau berdasarkan Dietary Reference Intake (DRI) adalah serat $20 \mathrm{~g} / \mathrm{hari}$ atau $14 \mathrm{~g} / 1000 \mathrm{kkal}^{28}$, dan vitamin C $75 \mathrm{mg} / \mathrm{hari}$ atau $63,6 \mathrm{mg} / 1000 \mathrm{kkal} .{ }^{29}$ Asupan serat dan vitamin C pada kelompok kontrol kurang jika dibandingkan dengan anjuran yang direkomendasikan per $1000 \mathrm{kkal}$.

Vitamin C sebagai antioksidan yang larut dalam air dapat mencegah terjadinya oksidasi. Vitamin $\mathrm{C}$ dapat mengurangi kadar trigliserida dalam darah, sehingga apabila ada gangguan kekurangan vitamin $\mathrm{C}$, maka dapat mengakibatkan peningkatan kadar trigliserida. Vitamin $\mathrm{C}$ sebagai kofaktor menstimulasi pemakaian asam lemak dalam sel hati yang dapat mengurangi kadar trigliserida dalam darah. ${ }^{30}$ Konsumsi serat yang memenuhi kebutuhan, diketahui dapat meningkatkan ekskresi lemak melalui feses sebanyak 2-4 g/hari. ${ }^{31}$ Serat akan mengikat lemak sehingga penyerapan lemak akan terganggu. Serat akan mengikat asam empedu dan membentuk misel yang akan dikeluarkan melalui feses. ${ }^{25}$ Apabila seseorang kurang mengasup serat, maka asam empedu akan memecah lemak yang kemudian diabsorbsi oleh usus halus. Pemecahan lemak akan menghasilkan asam lemak dan gliserol, dimana asam lemak dan gliserol adalah komponen penyusun trigliserida. ${ }^{32}$

Hasil uji statistik kadar trigliserida antar kelompok perlakuan dan kontrol sebelum pemberian intervensi tidak menunjukkan adanya perbedaan rerata yang bermakna. Rerata kadar trigliserida setelah intervensi pada kedua kelompok menunjukkan adanya perbedaan yang bermakna. Hal ini dikarenakan terjadi penurunan kadar trigliserida pada kelompok perlakuan dan peningkatan kadar trigliserida pada kelompok kontrol. Penurunan kadar trigliserida terjadi setelah pemberian sari bengkuang selama 21 hari.

\section{SIMPULAN}

Terdapat penurunan rerata kadar trigliserida sebesar $14,93 \mathrm{mg} / \mathrm{dl}$ setelah pemberian sari bengkuang yang diperoleh dari buah bengkuang seberat 320 gram.

\section{SARAN}

Diperlukan pengambilan data asupan zat gizi subjek sebelum intervensi.

\section{DAFTAR PUSTAKA}

1. Sawant, AM, Shetty D, Mankeshwar R, Ashavaid TF. Prevalence of Dyslipidemia in Young Adult Indian Population. Association of Physicians India Feb 2008. JAPI Vol. 56.

2. The World Heart Federation. The Millenium Development Goals and Cardiovascular Disease 2012 [cited 2014 March 16]. Uniting global efforts to fight heart disease and stroke. Available from URL : $\quad$ http://www.world-heartfederation.org/what-we-do/advocacy/global-

health-agenda/health-and-development-golas-andcardiovascular-diseases/

3. Profil Kesehatan Provinsi Jawa Tengah. 2011[serial online] [cited 2014 March 18] Available from: URL: http://jateng.bps.go.id/index.php

4. Laporan Dinas Kesehatan Kota Semarang. Rekapitulasi Data Kesakitan Tahun 2012.

5. Goff DC, Bertoni AG, Kramer H, Bonds D, Blumenthal RS, Tsai MY, Psaty BM. Dyslipidemia Prevalence, Treatment, and Control in the Multi-Ethnic Study of Atherosclerosis (MESA): Gender, Ethnicity, and Coronary Artery Calcium. Circulation-Journal of American heart association, 2006 Vol. 113:647-656. USA.

6. Anwar, Bahri T. Dislipidemia Sebagai Faktor Resiko Penyakit Jantung Koroner. 2004. Medan: Universitas Sumatera Utara.

7. Rani R, Durchame N. Hyperlipidemia in the Elderly. Division of Endocrinology, Saint Louis University Medical Center. 1402. 2008 South Grand Boulevard, Donco Building, 2nd Floor, St. Louis, MO 63104. USA

8. Supriyono M, Soeharyo H. Faktor-faktor Risiko Kejadian Penyakit Jantung Koroner (PJK) Pada Kelompok Usia < 45 tahun (Studi Kasus di RSUP Dr. Kariadi Semarang dan RS Telogorejo Semarang. Available from URL : http://eprints.undip.ac.id/6324/1/. Program Magister Program Epidemiologi Program Pascasarjana Universitas Diponegoro. [serial online] 2008 [cited 2014 March 18].

9. Nadimin. Pola Makan, Aktivitas Fisik dan Status Gizi Pegawai Dinas Kesehatan Sulawesi Selatan. Media Gizi Pangan, Vol. XI, Edisi 1, Januari Juni. 2011. Jurusan Gizi Politeknik Kesehatan Kemenkes Makassar

10. Dewi AC. Hubungan Pola Makan, Aktivitas Fisik, Sikap dan Pengetahuan Tentang Obesitas dengan Status Gizi Pegawai Negeri Sipil di Kantor Dinas Kesehata Provinsi Jawa Timur. 2011. Program Studi Kesehatan Masyarakat, UNAIR. Available from URL : 
unair.ac.id/detail.php?id=43111\&faktas=Kesehata n\%20Masyarakat

11. Kyun, Park Sung .Fruit, vegetable, and fish consumption and heart rate variability: the Veterans Administration Normative Aging Study1-3. Am J Clin Nutr 2009;89:778-86.

12. Putri, Tia. Usaha keripik bengkoang guna meningkatkan nilai jual buah bengkuang. 2010. Available from: URL

http://sangputristory.blogspot.com/2010/05/usahakeripik-bengkuang- guna-html.

13. Reimer RA, Grover GJ, Koetzner L, Gahler RJ, Lyon MR, Wood S. The Soluble Fiber Complex PolyGlycopleX Lowers Serum Triglycerides and Reduces Hepatic Steatosis in High-sucrose-fed Rats. Faculty of Kinesiology and Department of Biochemistry \& Molecular Biology, University of Calgary, Calgary, Alberta, Canada T2N 1N4, Department of Physiology and Biophysics, Robert Wood Johnson Medical School, Piscataway, NJ 08854, USA. Nutrition Research 31 (2011) 296301

14. Khogare DT. Effect of dietary fiber on blood lipid profile of selected respondent. UGC Major Research Project, Dept. of Home Science, Government Rajaram College, Kolhapur (MS) India. International Food Research Journal 19(1): 297-302 (2012)

15. Setyadi AW, F Junianto, Yulianti E. Pengaruh Sari Bengkuang (Pachyrizua Erosus) Terhadap Penurunan Kolesterol pada Tikus Putih (Rattus Norvegicus) STIKes Bhakti Mulia : 2013. Pare Kediri

16. Pandey, Kanti B, Syed IR. Plant Polyphenols as Dietary Antioxidants in Human Health and Disease. Department of Biochemistry; University of Allahabad; Allahabad, India. Oxidative Medicine and Cellular Longevity 2:5, 270-278; November/December; 2009. Landes Bioscience

17. Fuad, Himmatul. Pengaruh Ekstrak Bengkuang (Pachyrhizus erosus) terhadap Kadar Trigliserida Darah Tikus Putih (Rattus norvegicus) yang Diberi Diet Tinggi Lemak. Universitas Negeri Solo : 2014. Solo

18. Baecke JAH Burema J Frijters ER. A short questionnaire for the measurement of habitual physical activity in epidemiological studies. Am J Clin Nutr. 1982; 36: 936-942.

19. Supariasa, IDN., Bachyar B., Ibnu F. Dalam : Ester M,editor. Penilaian Status Gizi. Cetakan I. Jakarta- Penerbit Buku Kedokteran : EGC. 2002. p.60-61

20. McRae M. Vitamin C Supplementation Lowers Serum Low-Density Lipoprotein Cholesterol and Triglycerides; A Meta-Analysis of 13 Randomized Controlled Trials. Journal of Chiropratic Medicine 2008;7:48-58.

21. Asia Pacific Cohort Studies Collaboration. American Heart Association. Serum Triglyceride as a Risk Factor for Cardiovascular diseases in the
Asia-Pacific region. Circulation.2004;110:26782686

22. Miller Michael, dkk. Triglycerides and Cardiovascular Disease : A Scientific Statement from the American Heart Association. Circulation. 2011;(123):2292-2333

23. Institute of Medicine of the National Academies. Dietary Reference Intakes for Energy, Carbohydrate, Fiber, Fat, Fatty Acids, Cholesterol, Protein, and Amino Acids. 2005. Available from URL

http://www.nal.usda.gov/fnic/DRI/DRI_Energy/en ergy_full_report.pdf

24. Diaz DF Gracia, dkk. Vitamin C Inhibits Leptin Secretion and Some Glucose/Lipid Metabolic Pathways in Primary Rat Adipocytes. Journal of Molecular Endocrinology 2010;45,33-43

25. Yang Ronghua, Lili A Barouch, Leptin Signaling and Obesity : Cardiovascular Consequences. Circ Res 2007;101:545-559

26. Yap HC, Kui KL, Kai HY, Sheung WL, Hiu TC, Sidney T, Xiao OS, Chu PL, Hung FT. Isoflavone intake in persons at high risk of cardiovascular events: implications for vascular endothelial function and the carotid atherosclerotic burden. Am J Clin Nutr 2007;86:938-45.

27. Tornheim K, Ruderman NB. Dalam : Ahima, RS, editor. Intermediary Metabolism of Carbohydrate, Protein, and Fat. Chapter 2. Department of Biochemistry, Boston University School of Medicine, Silvio Conte Building. 2011

28. American Dietetic Association. Health Implications of Dietary Fiber. J Am Diet Assoc. 2008;108:1716-1731

29. The National Academies. Dietary Reference Intakes for Vitamin C, Vitamin E, Selenium and Carotenoids. 2001. Available from URL : http://www.nap-edu

30. McRae MP. Vitamin C Supplementation Lowers Serum low-density lipoprotein cholesterol and triglycerides : a meta-analysis of 13 randomized controlled trials. J Chiropr Med. Jun 2008; 7(2): 48-58

31. Lisa Brown, Bernard Rosner, walter W, Frank M sacks. Cholesterol lowering effects of dietary fiber: a meta-analysis. [serial online] 1999 [cited 2014 July 21] 69:30-4. Available from : http://ajcn.nutrition.org/content/69/1/30.full.pdf+ht $\underline{\mathrm{ml}}$

32. Lattimer JM, Haub MD. Effects of Dietary Fiber and Its Components On Metabolic Health. Dept. of Human Nutrition, Kansas State University. Nutrients 2010, 2, 1266-1289 